\title{
Are taxpayers, who pay their taxes, all cooperative citizens?
}

Jérémy Lemoine, University of Reims Champagne-Ardenne

Christine Roland-Levy, University of Reims Champagne-Ardenne

\begin{abstract}
France does not have a classical withholding tax system; taxes are calculated on the basis of the previous year declaration of income. Moreover, France is, in terms of corruption (Transparency index, Corruption Perceptions Index, 2011), in the 25th row, behind many of the European countries, which indicates a very high perception of corruption in France, compared to the other European countries. In this article, the focus is on the psychological effect of this system and its consequences in terms of tax compliance versus tax evasion, which can be seen in terms of cooperation versus competition. This study, in line with E. Kirchler's research on tax evasion, investigates the links between powers of authorities, trust in authorities, and tax compliance in the French context. Moreover, along with Kirchler et al.'s (2008) work, our goal was to test the 'slippery slope' framework on tax compliance with a sample of French citizens. In order to test it, trust in authorities and power of authorities were manipulated with four different scenarios (high trust/high power; high trust/low power; low trust/high power; low trust/low power). French university students in economics (320) were randomly assigned to one of the four conditions, in which they read one of the scenarios and had to answer a questionnaire composed of 24 items. In this article, tax compliance is approached in terms of cooperation versus competition; for this, we examined: if citizens comply in a cooperative way; if they have a competitive attitude towards tax authorities, indicating
\end{abstract}


that they try to evade taxes as much as possible, thus go against the collective goal because they have self-oriented motivations; or if they have a competitive attitude towards authorities because they do not consent government's policies. This study, which had two main facets, enabled identifying tax compliance in terms of trust in authorities and power of authorities, and allowed identifying cases in which conformity is voluntary, which implies cooperation; or forced, which implies that authorities impose compliance. Based on our results, the article concludes that both an increase of trust in the authorities and an increase of power of the authorities create an increase of tax compliance, which tends to show that, based on distrust, fraud is non-cooperative, and can be sometimes considered as competitive, as it is placing self-interest into the foreground instead of public interest.

\section{Keywords}

tax compliance

trust

power

cooperation

competition

'slippery slope’ framework 


\section{Introduction}

The Transparency International index (2012) defines corruption as 'the abuse of entrusted power for private gain'; it implies that corruption can be found at different levels, such as the political level with the manipulation of policies, or in everyday life, with for example tax evasion. The Corruption Perceptions Index (CPI) publishes each year an index about how corruption is perceived by the citizens in each country; the $2011 \mathrm{CPI}$ indicates that France is the 25 th, on the annual ranking of the countries, with a higher rate of corruption's perception than all the other countries of the G8 (except Italy and Russia). Results on corruption from the Eurobarometer ${ }^{1}$ support the results of the CPI, as they indicate that $71 \%$ of French people think that there is corruption in France, and $45 \%$ believe that corruption has increased during the past three years, against only $3 \%$ who think that corruption has decreased.

Evading taxes is here seen as an act of corruption, as it can imply voluntarily omitting to declare income, underestimating the amount to declare, increasing expenses, clandestine work, etc. In fact, tax fraud, as an illicit act consisting of reducing illegally one's taxes, is a major public problem in France; for example, in June 2010, the French Minister of Economy, François Baroin, announced that 3.4 billions of tax fraud were detected in France. In consequence, most of the candidates in the 2012 French presidential election, proposed, in their programme, measures to reduce tax fraud.

Starting with the French data related to corruption along with billions of tax fraud in France, in this article, we aim at showing that tax evasion, as a specific case of corruption, is a competitive act, rather than an act of citizenship, versus tax compliance, which we link to cooperation as it is placing public interest in the foreground; moreover, 
we want to see if taxpayers who declare all their income and who pay their taxes, are really cooperative citizens. We postulate, in this article, that compliance and cooperation can work hand in hand; in fact, cooperation is based on trust and on a more or less equal relationship in which parties agree with certain goals. Nevertheless, compliance is not always connected to cooperation, as it can be based on power and authority, as well as on threat of fines, etc. Fraud, especially if it is based on distrust, is non-cooperative and competitive as it is placing self-interest into the foreground instead of public interest, and also if it is about avoiding the inferior position that the authority out-rules and fraud tricks it and tries to overcome the authority... In fact, paying taxes can be based on cooperation or on plain compliance, while tax evasion can be non-cooperation (distrust or selfishness) and non-compliance, in connection with competition.

This article, in line with Kirchler's research on tax evasion (2007), as well as with Kirchler et al.'s work (2008) on the 'slippery slope' framework, analyses the results along the competition and cooperation framework.

\section{Tax fraud framework}

\section{Paying taxes is an act of citizenship}

The French Academy, the institution in charge of defining the French language, defines the word citizen as: 'belonging to the State, with all the civil rights and political rights'. The notion of civil duty does not appear in this definition. However, the Universal Declaration of Human Rights describes the rights of humans as well as their duties. 
(1) Everyone has duties to the community in which alone the free and full development of personality is possible. (2) In the exercise of rights and freedom, everyone shall be subject only to such limitations, which are determined by law solely for the purpose of securing recognition and respect for the rights and freedom of others, and of meeting the just requirements of morality, public order and the general welfare in a democratic society. (3) These rights and freedom may, in no case, be exercised contrary to the purpose and principles of the United Nations. (Article 29, UDHR)

In France, the relations between the administration and French citizens originate from the French Declaration of the Human Rights and of the Citizen (1789).

1. Law is the expression of the general will (Article 6, DHRC 1789).

2. Tax 'ought to be equally apportioned among all citizens according to their means' (Article 13, DHRC 1789).

3. 'All the citizens have a right to ascertain, by themselves or by their representatives $[\ldots]$ the quota, the assessment, the collection and the duration' of tax. (Article 14, DHRC 1789)

Therefore, based on the French Declaration of the Human Rights and of the Citizen (1789), and according to the above three articles, we can state that, for French citizens, 
law arises from the citizens; taxes are fair and everyone is equal when facing taxes; and that citizens accept to pay taxes as long as they perceive the amount to be fair. If citizens perceive taxes to be fair, it implies that they believe that taxes will be used properly by the government and that they trust that the government will distribute taxes in a fair way.

\section{Paying taxes is a public good act}

From R. W. McGee (2006), based on M. T. Crowe's writing (1944), ethics of tax evasion can be approached in three different perspectives: tax evasion is never ethical; tax evasion is always ethical; and tax evasion is sometimes ethical, depending on the facts and the circumstances. In this article, we consider that 'a democratic' government works for the general welfare; therefore, we take the perspective which states that tax evasion is never ethical and that paying taxes can be seen as a contribution to the provision of public good in a democratic society.

Various studies focus on how public goods' usage is perceived (e.g. Kemp 2002); moreover, in what is known as 'the public good framework', researchers study the behaviour of a group of individuals who have received money, but have to split the amount into two possible types of investments: one is private investment, while the other is public one. There are numerous different procedures (cf. Ledyard 1995), but in most of them, the dominant strategy chosen appears to be to invest everything in the private sphere. In line with this result, two major types of behaviour emerge from public good games $^{2}$ : free-riding ${ }^{3}$ and conditional cooperation ${ }^{4}$. The free-riders hypothesis (first, articulated by M. Olson (1971)) postulates that people are rational and selfish. R. M. Dawes and R. H. Thaler (1988) give the following description of free-riders: 
People are assumed to be clever enough to figure out that defection, or free-riding, is the dominant strategy, and are assumed to care nothing for outcomes to other players; moreover, people are assumed to have no qualms about their failure to do 'the right thing'. (Dawes and Thaler 1988: 187)

However, since P. Bohm's study on free-riding (1972), it has been shown that people may accept to contribute voluntarily to the provision of public goods. For J.-J.Laffont (1975) the human being is capable of non-selfish behaviour, and by following the 'Kantian'5 rule, people go beyond selfish maximization. According to R. Sugden (1984), people follow a 'morality of cooperation' (Sugden 1984: 774) and behave as they wish others should behave. In a survey of the literature on voluntary contributions, J. O. Ledyard (1995) found that contributions to public goods are, on average, in experimental studies, provided by 40 to 60 per cent of the participants; thus it indicates a high tendency for conditional contributions.

Contrary to most experiments in public good game research, U. Fischbacher et al. (2001) used a specific procedure, which enables to control long-term strategies, reputation building, and therefore to have 'an unambiguous measure of the participants' willingness to be conditionally cooperative' (2001: 400). Results point out that, about half of the participants were conditional cooperators, which implies that they were willing to contribute to public goods, but, at the same time, they expected others to also contribute to public goods. Almost one-third of the participants were free-riders who never cooperated, even when others did. The remaining $1 / 6$ th was mainly composed of 'humpshaped' contributors who, for small amounts, behaved like conditional cooperators, 
increasing their contribution as others increased it; they did so until the contribution corresponded to the half of their stake and then, they constantly decreased their contribution (Chaudhuri and Paichayontvijit 2006).

\section{Is paying taxes a cooperative act?}

In a democratic society, tax paying should be considered as a cooperative act by the citizen, instead of a compliant act based on authorities. Based on this postulate, for R. H. Weigel et al.(1987), tax evasion is thought of as an uncooperative act. Two contrasted types of motivations can explain this uncooperative act. The first one is self-oriented, citizens can be considered as free-riders, they try to evade taxes in order to keep their money for themselves; whereas, the second is oriented towards the other, citizens do not want to pay their taxes because they do not agree with the politics of the government; in this case, not paying taxes is a form of social criticism.

During the last century, most research on competition and cooperation was shaped around M. Deutsch's conception (1949). For him, people cannot be cooperative and competitive at the same time. According to M. Fülöp (2003, 2004), up to the 1990s, 'cooperation and competition have been conceptualized as two extremes or polar opposites of a single behavioural spectrum' (Fülöp 2004), in which cooperation was described as healthy and competition as destructive. This is called by her the 'Beauty and the Beast Paradigm' (Fülöp 2008).

At the beginning of the 1990s, there has been a paradigm change in the psychological literature. Cooperation and competition were not anymore considered as opposed; on the contrary, rivals were perceived rather as partners than as enemies (van de Vliert 1999). 
Cooperation and competition are not seen as mutually exclusive; they are parallel motivations (Fülöp 2003), which can both cohabit in the same individual (Carnevale and Probst 1997). The notion of competition changed from a unidimensional concept to a multidimensional one (Fülöp 1992; Tassi and Schneider 1997). Depending on the focus of the competitive process (Griffin-Pierson 1990; Tassi and Schneider 1997; Fülöp 2009) competition creates a different interpersonal relationship between the competititors. If the goal of competition is other-referenced i.e. to win over the other, then there is not much room left for a combination of cooperation and competition among the rivals. Competition becomes destructive (Fülöp 1992). If there is a common goal, and if the competition is goal or task oriented then there will be space for the combination of competition with cooperation, self-interest and joint interest, competition can be constructive (Fülöp 1992, 2009).

Beyond this distinction, cooperators and destructive competitors can be connected to the two behaviours observed in public good games. Cooperators are connected to conditional cooperating, which combines individual and public interest, while destructive competitors to free-riding, that only expresses individual interest against the public interest. According to Fülöp (2009), in a society, the goal is to have citizens who are able to combine individual and public good, who are cooperatively competitive citizens.

\section{What drives citizens to pay taxes?}

\section{Exogenous variables}

In a review of the literature, Kirchler et al. (2007) examine the results of studies arising from the standard model of tax evasion in relation with income (Allingham and Sandmo 
1972; Srinivasan 1973). This model frames tax compliance as a decision process under uncertainty; it describes factors that influence the judgment of people in the choice of paying, or not paying, taxes. There are, according to M. G. Allingham and A. Sandmo (1972), as well as to T. N. Srinivasan (1973), at least four factors that may influence tax evasion: the level of income, the tax rate, the audit probability and the amount of possible fines. Kirchler et al. (2007) explore the results of these four variables on the compliance of people in paying taxes. They conclude that 'most of [these] parameters have unstable and unclear effects and it is hard to draw definite conclusions from [previous] studies' (2007: 20).

\section{The 'slippery slope' framework}

Kirchler (2007) introduced the 'slippery slope' framework, which suggests that tax compliance comes from individual and social variables, rather than from exogenous variables.

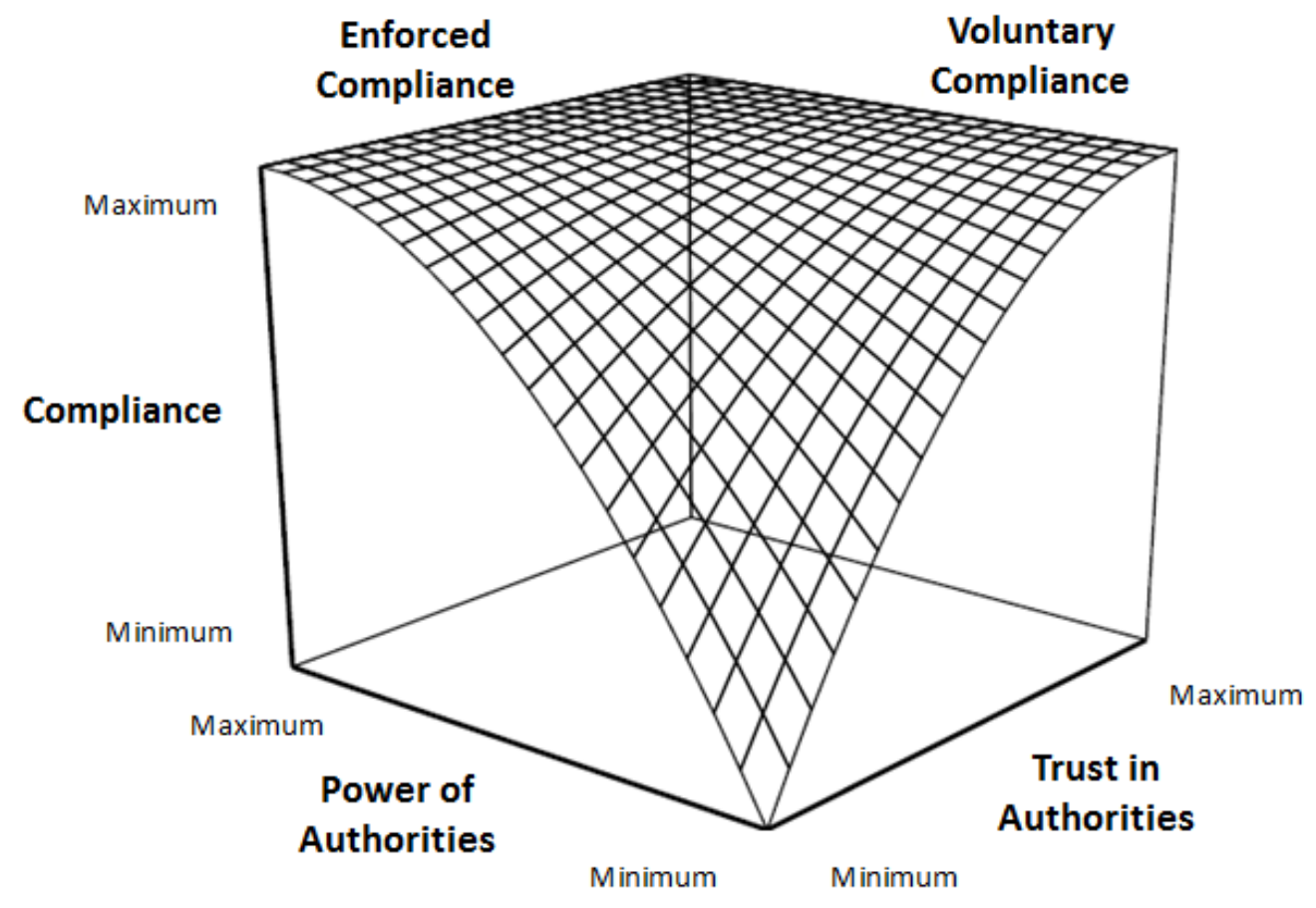


Figure 1: The 'slippery slope' framework (Kirchler 2007).

In the 'slippery slope' framework, two dimensions mainly influence tax compliance: the degree of trust in authorities and the level of power of authorities, as well as their interaction (Kirchler 2007; Kirchler et al. 2008; Kirchler and Wahl 2010; Wahl et al. 2010).

\section{Trust in authorities}

Kirchler et al. define trust in authorities as being 'a general opinion of individuals and social groups that the tax authorities are benevolent and work beneficially for the common good' (2008:. 212). For B. Torgler and F. Schneider, 'attitudes towards paying taxes can be seen as a proxy for tax morale' (2005: 232). Torgler (2003), and Torgler and Schneider (2005), based on findings from previous surveys (World Values Survey (WVS), Taxpayer Opinion Survey (TOS) and the European Values Survey (EVS)) indicate the presence of a link between trust in the government and tax moral. In this context, I. Wahl et al. (2010) created two experiments: the first took place in a laboratory with students, while the second was based on an online questionnaire with self-employed taxpayers. Results show that, in both cases, trust in authorities has an influence on tax compliance. These authors also found that trust in authorities has a positive effect on tax compliance. 


\section{Voluntary compliance}

According to the 'slippery slope' framework, trust in authorities encourages taxpayers' compliance. In a situation of high trust, taxpayers tend to consider that authorities act in a fair way. If taxpayers tend to view 'their tax share as a fair contribution to the public good' (Kirchler et al. 2008), they tend to comply voluntarily. On the contrary, in a situation of low trust, taxpayers tend to be suspicious towards authorities and do not act voluntarily in a cooperative way. An increase of trust should therefore lead to the increase of the number of people who will be cooperators and thus whom will voluntary comply with their tax obligations.

\section{Power of authorities}

Kirchler et al. define the power of authorities as '...taxpayers' perception of the potential of tax officers to detect illegal tax evasion, for example by conducting frequent and thorough tax audits, and to punish evasion, for example by fining evaders to a noticeable extent' (2008: 212). In their definition of power, Kirchler et al. (2008) emphasize that it is not the real power of authorities that matters, but the perception that taxpayers have of this power.

This is in line with C. M. Fischer et al.'s (1992) suggestion which states that authorities' power do not have an objective deterrent effect in order to have a high level of compliance, but it is moderated by taxpayers' perceptions and subjective evaluations of authorities' abilities to detect tax frauds and to deter evasion. With their two empirical studies, Wahl et al. (2010) found that the power of authorities affects tax compliance and that the perception of power of authorities has a positive effect on tax compliance. 


\section{Enforced compliance}

Moreover, according to the 'slippery slope' framework, power of authorities encourages taxpayers' compliance. In a situation of high power, the detection probability increases along with the increase of the number of audits and with fines, which are costly. Thus 'taxpayers have less and less incentive to evade, as the expected outcome of noncompliance falls below the expected outcome of compliance' Kirchler et al. 2008), and they are enforced to comply.

In a situation of low power, authorities do not have means to constrain destructive competitors to comply. Trust does not have an impact on them, as they seem to be selfish free-riders. In that case, authorities need to have a strong power to enforce them to comply their tax obligations. Therefore, an increase of power should lead to an increase of enforced tax compliance.

\section{Connections between power and trust}

Trust and power are two factors that are not independent one of the other, as a change of one can also have an influence on the other one (Kirchler 2007; Kirchler et al. 2008; Kirchler and Wahl 2010; Wahl et al. 2010). Change in power of the authorities may result in an increase, or a decrease, of trust; this will depend on the way the change is perceived. An increase of power may be perceived by some as mistrustful towards taxpayers, and by others as a voluntary act of equity of taxpayers towards the law; on the other hand, a decrease of power may be perceived by some as a sign of trust towards taxpayer, and by others as a sign of not serving well the collective goal, as well as a sign of cooperation towards evading taxpayers (Wahl et al. 2010). 
As we have shown, based on the 'slippery slope' framework, tax compliance should mainly be influenced by two dimensions: the degree of trust in authorities and the level of power of authorities, as well as their interaction, and this is what we tested on a French sample of university students.

\section{Method}

\section{Overview}

The aim of this study was to answer the following question: are taxpayers who pay their taxes, all cooperative (voluntarily paying taxes, willing to contribute to the public good) or compliant citizens (submissive to power)? How can destructive competition, free riding taking advantage of others, be avoided? This article, in line with Kirchler's research on tax evasion (2007), as well as with Kirchler, et al.'s work (2008) on the 'slippery slope' framework, examines the results along these distinctions.

The 'slippery slope' framework indicates that: an increase of trust in the authorities or an increase of power in the authorities leads to an increase of tax compliance; an increase of trust involves an increase of voluntary tax compliance (cooperation); an increase of power involves an increase of enforced tax compliance; changes in trust should have an influence on the perception of power, and changes in power should have an influence on the perception of trust and as a consequence on the number of those citizens who commit tax evasion. 


\section{Participants}

In our study, 328 French university students in economy completed our questionnaire. Eight participants did not answer all the questions, and were excluded from our analysis. Thus, results are based on a sample of 320 participants (151 females/169 males; all of them were aged between 18 and 25; $M=21.46$ years, $\mathrm{SD}=1.96)$. Most participants declared having small personal income and have never paid taxes, which implies that they are not necessarily aware of what paying taxes really implies.

Since trust in authorities and power of authorities were manipulated with four different conditions (high trust/high power; high trust/low power; low trust/high power; low trust/low power), each participant was allocated to one of the four conditions; thus, our sample of 320 participants was separated in four groups, with 80 participants in each of the four conditions.

\section{Materials and procedure}

Participants answered individually the paper and pencil questionnaire during a class period. The survey was composed of three parts: a text describing an imaginary country (Varosia), questions about tax compliance, and socio-demographic questions.

In order to test our hypotheses, four different scenarios were presented on the basis of an adaptation of the scenarios used in study of Wahl et al. (2010), in which participants had to read a description of a fictitious country, Varosia, this country having the same demographic description as France (same number of inhabitants and same type of geographical size). Each scenario varies in terms of the description of Varosia on two factors: the trust that citizens have in their country and the power that they attribute to 
their government. The four scenarios correspond to the four conditions (high trust/high power; high trust/low power; low trust/high power; low trust/low power).

After reading the scenario, participants were instructed to imagine themselves as citizens of Varosia: living, working and paying taxes in Varosia. They were instructed to imagine themselves as a self-employee whose business is running good. Their tax declaration is due and they have to pay taxes.

Then, they answered the questionnaire composed of 24 items, most of them having already been used in various previous studies. Nine items come from Wahl et al.'s work (2010): three items to measure intended tax compliance, six items as manipulation checks; three items for trust, and three others for power. Fifteen items stem from Kirchler and Wahl's study (2010): five items to measure enforced compliance, five items to measure voluntary tax compliance, and five items to assess tax evasion.

Finally, participants were asked to fill in the last part concerning socio-demographic information. Participants gave information concerning their sex, age, type of studies, level of study, personal monthly income and family monthly income, in order to be able to analyse the data according to these specific variables, and in particular to see how familiar they were with income taxes.

\section{Results}

\section{Perception of trust and power}

In order to verify if the four conditions emphasize different levels of trust in the authorities and of power of the authorities, three items measure the perception of the level of trust in the authorities, while three items measure the perception of the level of power 
of the authorities. The Cronbach's $\alpha$ of the three items on trust, as well as the three items on power, are both equal to 0.82 , which is satisfactory. The multivariate analysis reveals an interaction effect $\left(F(2,315)=9.86, p<0.001, \eta^{2}=0.06\right)$, a main effect of trust $\left(F(2,315)=207.06, p<0.001, \eta^{2}=0.57\right)$, and of power $(F(2,315)=155.63, p<0.001$, $\left.\eta^{2}=0.50\right)$

The univariate results of trust show that participants who read a trustworthy description of Varosia's authorities, trust authorities more than participants who read an untrustworthy description of Varosia's authorities $\left(F(1,316)=413.24, p<0.001, \eta^{2}=0.57\right.$; low trust: $M=2.81, \mathrm{SD}=1.50$; high trust: $\mathrm{M}=6.32, \mathrm{SD}=1.73) .{ }^{7}$ There is an effect of the manipulation of power on the perception of trust: people who were confronted to a powerful description of Varosia's authorities, trust Varosia's authorities more than participants who were confronted to a description of Varosia's in which the power of the authorities is weak $\left(F(1,316)=17.09, p<0.001, \eta^{2}=0.05\right.$; low power: $M=4.21, \mathrm{SD}=2.08$; high power: $M=4.92, \mathrm{SD}=2.62$ ). There is also an interaction of trust and power on the perception of trust $\left(F(1,316)=18.51, \mathrm{p}<0.001, \eta^{2}=0.06\right)$. This interaction between trust and power reveals that the perception of trust in the authorities is the highest when the authorities are presented as trustworthy and as having a strong power $(M=7.05$, $\mathrm{SD}=1.57)$, compared to when authorities are presented as trustworthy and as having a weak power $(M=5.59, \mathrm{SD}=1.58)$, than when authorities are presented as untrustworthy and as having a weak power $(M=2.83, \mathrm{SD}=1.54)$; and, when authorities are presented as untrustworthy and as having a strong power $(M=2.8, \mathrm{SD}=1.47)$. Analyses were also conducted for the variables sex, age, level of study, personal income and family income, but none of these variables has a significant effect on the perception of trust 
$(F(1,312)=0.68, p=0.41 ; F(6,292)=1.29, p=0.26 ; F(1,312)=1.72, p=0.19 ; F(4,300)=1.13$, $p=0.34$ and $F(4,300)=0.36, p=0.84$, respectively).

The univariate results of power show that participants who read a powerful description of Varosia's authorities perceive Varosia's authorities as more powerful than those who read a description of Variosia's in which authorities are weak $(F(1,316)=312.15$, $p<0.001, \eta^{2}=0.50$; low power: $M=3.41, \mathrm{SD}=1.60$; high power: $\left.\mathrm{M}=6.75, \mathrm{SD}=1.84\right)^{8}$. There is also an effect of the manipulation of trust on the perception of power: participants confronted to a trustworthy description of Varosia's authorities, perceived Varosia's authorities as more powerful than participants confronted to an untrustworthy description of Varosia's authorities $\left(F(1,316)=13.40, p<0.001, \eta^{2}=0.04\right.$; low trust: $M=4.73, \mathrm{SD}=2.46$; high trust: $M=5.43, \mathrm{SD}=2.30$ ). There is no interaction of trust and power on the perception of power $(F(1,316)=0.00, p=0.99)$. Analyses were also conducted on the variables sex, age, level of study, personal income and family income, but none of these variables has a significant effect on the perception of power $(F(1,312)=2.94, \mathrm{p}=0.09$; $F(6,292)=1.54, p=0.16 ; F(1,312)=0.56, p=0.46 ; F(4,300)=1.42, p=0.23$ and $F(4,300)=0.35, p=0.85$, respectively). 


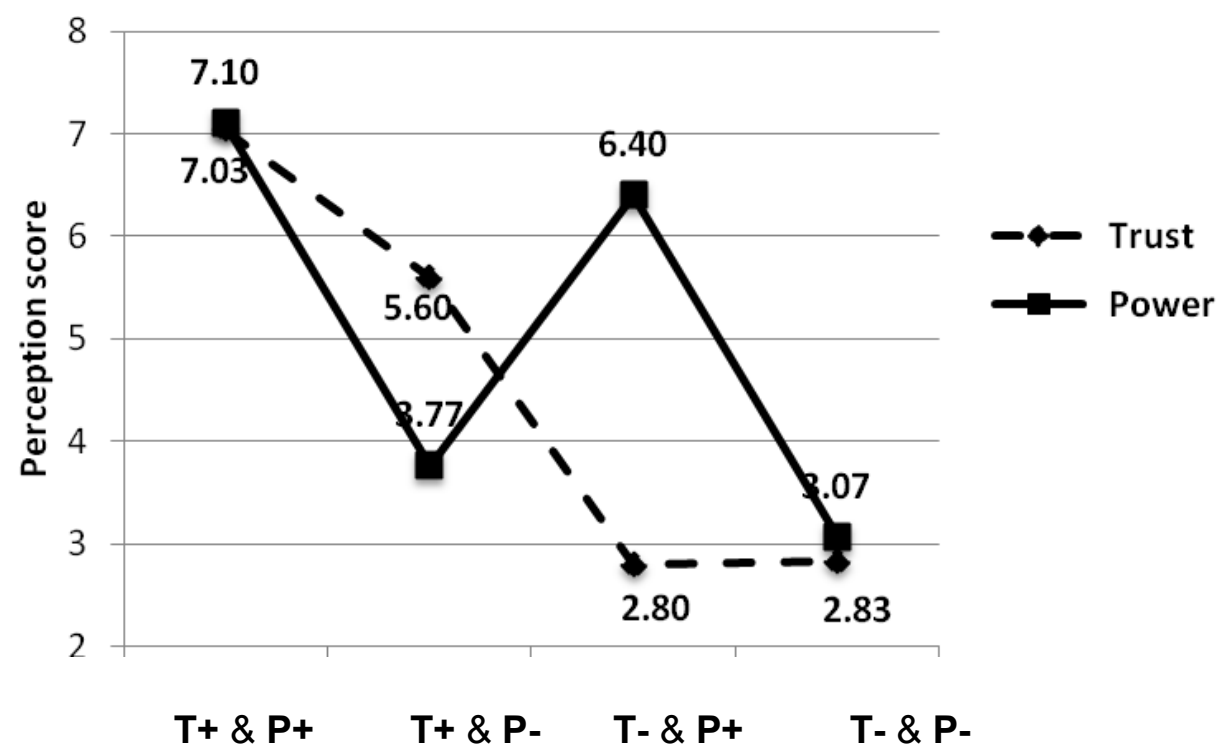

Figure 2: The perception of trust and power.

These results indicate that the descriptions of Varosia's authorities, as they are presented in the different scenarios, appear to be good. That implies that Varosia's authorities are perceived as more trustworthy in a situation described as high trust, than in a situation described as low trust. The description of Varosia's authorities, with strong power, is perceived as more powerful than the description of Varosia's authorities with weak power.

\section{Tax compliance}

Three items measure tax compliance; the Cronbach's $\alpha$ of these items is 0.80 , which is considered as an acceptable level of confidence for the data gathered from these items. In order to analyse tax compliance, a factorial ANOVA was calculated with trust, power and sex as independent variables. Analyses indicate a main effect of trust, power and sex. Participants in the high trust condition appear to have more tax compliance than people in 
the low trust condition $\left(F(1,312)=39.99, p<0.001, \eta^{2}=0.11\right.$; low trust: $M=5.31, \mathrm{SD}=2.29$; high trust: $\mathrm{M}=6.74, \mathrm{SD}=1.87) .{ }^{9}$ Participants in the high power condition appear to have more tax compliance than participants in the low power condition $(F(1,312)=37.39$, $p<0.001, \eta^{2}=0.11$; low power: $M=5.35, \mathrm{SD}=2.13$; high power: $M=6.70, \mathrm{SD}=2.07$ ). The Scheffe post hoc test confirms that participants in the high trust and high power condition $(M=7.43, \mathrm{SD}=1.49)$ were those who comply significantly the most, compared to those in the high trust and low power condition $(M=6.04, \mathrm{SD}=1.95)$, low trust and high power condition $(M=5.97, \mathrm{SD}=2.30)$ and low trust and low power condition $(M=4.67$, $\mathrm{SD}=2.10$ ). The Scheffe post hoc test also indicates that participants in the low trust and low power condition were those who comply significantly the least. Women produce more tax compliance than men $\left(F(1,312)=5.92, p<0.05, \eta^{2}=0.02\right.$; women: $M=6.32$, $\mathrm{SD}=2.13$; men: $M=5.76, \mathrm{SD}=2.24)$. Analyses were also conducted for the variables age, level of study, personal income and family income, but none of these variables appears to have a significant effect on tax compliance $(F(6,292)=1.45, p=0.20 ; F(1,312)=1.76$, $p=0.19 ; F(4,300)=0.76, p=0.55$ and $F(4,300)=52.88, p=0.20$, respectively).

\section{Voluntary tax compliance (cooperation) and enforced tax compliance}

Five items measure the level of voluntary tax compliance and five items measure the level of enforced tax compliance. The Cronbach's $\alpha$ of the five items of voluntary tax compliance and of the five items of enforced tax compliance are respectively of 0.81 and of 0.89 , both Cronbach's $\alpha$ being of good level. The multivariate analysis of trust and power does not reveal an interaction $\operatorname{effect}(F(2,315)=0.30, p=0.74)$, but a main effect of trust $\left(F(2,315)=35.23, p<0.001, \eta^{2}=0.18\right)$ and a main effect of power $(F(2,315)=57.56$, $\left.p<0.001, \eta^{2}=0.27\right)$ are found. 
The univariate results of voluntary compliance indicate that participants confronted to a trustworthy description of Varosia's authorities have more voluntary tax compliance, are willing to cooperate more, than participants confronted to an untrustworthy description of Varosia's authorities $\left(F(1,316)=69.56, p<0.001, \eta^{2}=0.18\right.$; low trust: $M=4.83, \mathrm{SD}=1.64$; high trust: $M=6.28, \mathrm{SD}=1.49) .{ }^{10}$ There is no effect of the manipulation of power on voluntary tax compliance $(F(1,316)=1.41, p=0.24$; low power: $M=5.66, \mathrm{SD}=1.79$; high power: $M=5.45, \mathrm{SD}=1.65)$. There is no interaction of trust and power on voluntary tax compliance $(F(1,316)=0.45, p=0.50)$. Analyses were also conducted for the variables sex, age, level of study, personal income and family income. One of these variables, personal income, has a significant effect on voluntary tax compliance $(F(4,300)=4.19, p<0.01$, $\left.\eta^{2}=0.04\right)$. We have to take this result very carefully for two reasons: (1) the repartition of the participants on the income scale was very poor (199 participants in our sample have very low personal income (they are students), whereas only eleven have an average personal income, and nine have a high personal income); and (2) the Scheffe post hoc test indicates that there is no significant difference in voluntary tax compliance according to the different levels of personal income. None of the other variables (sex, age, level of study and family income) has an effect on voluntary tax compliance $(F(1,312)=1.12$, $p=0.29 ; F(6,292)=1.70, p=0.12 ; F(1,312)=0.04, p=0.83$ and $F(4,300)=0.60, p=0.67$, respectively).

The univariate results of enforced compliance indicate that participants, confronted to a description of Varosia's authorities with strong power, have more enforced tax compliance than participants confronted to a description of Varosia's authorities with weak power $\left(F(1,316)=115.49, p<0.001, \eta^{2}=0.27\right.$; low power: $M=4.09, \mathrm{SD}=2.00$; high 
power: $M=6.52, \mathrm{SD}=2.03)^{11}$. There is no effect of the manipulation of trust on enforced tax compliance $(F(1,316)=0.03, p=0.86$; low trust: $M=5.28, \mathrm{SD}=2.38$; high trust: $M=5.32$, $\mathrm{SD}=2.33)$. There is no interaction of trust and power on voluntary tax compliance $(F(1,316)=0.09, p=0.76)$. Analyses were also conducted for the variables sex, age, level of study, personal income and family income, but none of these variables has a significant effect on enforced tax compliance $(F(1,312)=3.13, p=0.08 ; F(6,292)=1.67$, $p=0.13 ; F(1,312)=2.96, p=0.09 ; F(4,300)=0.38, p=0.82$ and $F(4,300)=0.22, p=0.07$, respectively).

Table 1: Mean and standard deviation for tax compliance, voluntary tax compliance, enforced tax compliance and tax evasion.

\begin{tabular}{|l|l|l|l|l|}
\hline & \multicolumn{2}{|l|}{ Trust High } & \multicolumn{2}{l|}{ Trust Low } \\
\cline { 2 - 5 } & Power High & Power Low & Power High & Power Low \\
\hline Tax compliance & $7.43 \pm 1.49$ & $6.04 \pm 1.95$ & $5.97 \pm 2.30$ & $4.67 \pm 2.10$ \\
\hline $\begin{array}{l}\text { Voluntary tax } \\
\text { compliance }\end{array}$ & $6.24 \pm 1.43$ & $6.33 \pm 1.55$ & $4.66 \pm 1.48$ & $4.99 \pm 1.78$ \\
\hline Enforced tax & $6.58 \pm 2.03$ & $4.08 \pm 1.91$ & $6.46 \pm 2.03$ & $4.11 \pm 2.10$ \\
\hline compliance & & & & $5.81 \pm 1.80$ \\
\hline
\end{tabular}

\section{Tax evasion}

Five items measure tax evasion; the Cronbach's $\alpha$ of these items is 0.81 . In order to analyse tax evasion, a factorial ANOVA was calculated with trust and power as independent variables. Analyses indicate a main effect of trust $(F(1,316)=20.95, p<0.001$, 
$\eta^{2}=0.06$, low trust: $M=5.90, \mathrm{SD}=1.80$; high trust: $\left.M=4.98, \mathrm{SD}=1.78\right)^{12}$; participants, in the low trust condition, report more tax evasion than participants in the high trust condition. There is no effect of the manipulation of power on tax evasion $(F(1,316)=1.15, p=0.70)$. Also, there is no interaction of trust and power on tax evasion $(F(1,316)=1.52, p=0.22)$. Analyses were also carried out for the variables sex, age, level of study, personal income and family income, but none of these variables have a significant effect on tax evasion $(F(1,312)=2.20, p=0.14 ; F(6,292)=1.41, p=0.21 ; F(1,312)=0.04, p=0.85 ; F(4,300)=0.27$, $p=0.84$ and $F(4,300)=0.29, p=0.28$, respectively).

\section{Discussion}

The main goal of this study was to see if taxpayers who pay their taxes, are all cooperative citizens.

One of the assumptions of the 'slippery slope' framework states that the two variables, trust and power, both have an influence on tax compliance, via two different forms of tax compliance: voluntary tax compliance i.e. a cooperative act versus enforced tax compliance. As results indicate, voluntary tax compliance is influenced by mainly only one factor, trust in authorities, while enforced tax compliance is mainly influenced by the second factor: the power of the authorities. Our study clearly confirms this assumption.

Results from our study also demonstrate that both an increase of trust in the authorities and an increase of power of the authorities involve an increase of tax compliance, but via different psychological pathways. This increase of tax compliance can be organized in two directions: (1) in case of high trust, people voluntarily pay their taxes and cooperate to public goods, whereas (2) in case of no trust, or low trust, and strong power people are 
enforced to comply, but will not voluntarily cooperate. Participants in the high trust and high power condition are those who comply significantly the most, compared to the three other conditions; and, participants in the low trust and low power condition are those who voluntary comply significantly the least. Also, in line with the results found by Wahl et al. (2010) in their first experiment, with our study, we confirm that women report more voluntary tax compliance than men.

Overall, our results on the perception of trust and the perception of power also confirm, with a French sample, that the 'slippery slope' framework is a dynamic model in which change in trust influences the perception of power, and changes in power influence the perception of trust.

The five items concerning the measures of tax evasion come from an adaptation of Kirchler and Wahl's items (2010). They define tax evasion items as 'fictitious case scenario to state a concrete way of evading taxes'; they allow 'measuring the intention to reduce taxes illegally'. These items are used to detect the 'cops-androbbers" attitude. Wahl et al. (2010) found an interaction effect of trust and power on tax evasion. Tax evasion appeared to be lower when authorities are trustworthy and powerful, and higher when authorities are untrustworthy and powerful. These results point out the 'important role of trust in the decision to pay taxes' (Wahl et al. 2010). Our French results are not exactly the same; on the one hand, we found no interaction of trust and power on the measure of tax evasion, but, on the other hand, we found a main effect of trust. We found no effect of power on tax evasion. French participants in high trust conditions report less tax evasion than participants in low trust conditions, and this is independent of power. It suggests that only trust in the 
authorities has a real influence on tax evasion. This difference between the French and Austrian results is very interesting and requires further investigations. To our knowledge, this cannot be explained by differences in the level of confidence in their public institutions because Austrian and French people have almost the same level of confidence (respectively, 61 and 59 per cent (Organization for Economic Co-operation and Development (OECD) 2012)). Nevertheless, the fact that we only found an effect of trust can be explained in two ways: one theoretical and one methodological. The theoretical explanation comes from B. R. Jackson and V. C. Milliron (1986) who identified that a lack of trust in the government has a significant effect on tax evasion. Based on G. T. Tsakumis et al.'s study (2007), G. Richardson (2008) points out a link between trust in the government and tax evasion, i.e. trust in government has a negative influence on tax evasion. The methodological explanation is connected to the fact that tax evasion's items are items in which participants are able to omit to declare all their income, without taking the risk of being caught (e.g. You could intentionally declare restaurant bills for meals you had with your friends as business meals. How likely would you be to declare those restaurant bills as business meals?). Therefore, it is understandable that power does not have an effect on this measure of tax evasion.

The main limitation of our study is that it was conducted with students who globally have a low personal income, and who are not used to paying taxes. Nevertheless, Wahl et al.'s (2010) experiment on students and self-employed people found similar results on tax compliance, voluntary tax compliance, enforced tax compliance and tax evasion with both populations, students and self-employed. These studies suggest that experimenting 
with students about tax compliance is possible and allows obtaining results, which are similar to results found on self-employed people.

These results, similar to those from previous studies related to the 'slippery slope' framework, indicate that trust without power, in France, does not allow reaching the highest level of compliance. In our study, we have shown that trust encourages cooperative citizens to comply, but did not have any effect on both destructive competitors who free-ride and on those who do not agree with the government's politics, who do not pay taxes in order to protest. For them, a strong power of the authorities is necessary in order to comply. Therefore, taxpayers, who declare and pay their taxes, are not all cooperative citizens, since some comply voluntarily while others need to be strongly enforced to comply. The remaining question is how can we transform destructive competitors into cooperative citizens, in order to increase the level of voluntary tax compliance?

\section{Citizens education could increase tax compliance}

Researchers in the tax framework emphasize the importance of education in order to increase compliance. In fact, several studies showed that education and knowledge about taxation constitute a good lever to improve voluntary tax compliance (Groenland and van Veldhoven 1983; Kirchler and Maciejovsky 2001; Park and Hyun 2003). For example, K. Eriksen and L. Fallan (1996) carried out a study in which they found that increasing tax knowledge leads to a stronger tax ethics and a higher perception's of fairness of the tax system, which could lead to more voluntary tax compliance. Along this line, J. Alm (1991) also found a positive link between perception of fairness of the tax system and tax compliance. 
Moreover, E. Kirchler and B. Maciejovsky (2001) indicate that taxpayers, who have a lack of knowledge about enforcement strategies from the government, such as audits and fines, are not really able to anticipate the consequences of their evasion. For V. Braithwaite (2003a, 2003b), tax authorities should adopt both persuasion and education as their first enforcement strategy. It is only when this first enforcement strategy does not work that tax authorities should take the next step and use more severe sanctions. Kirchler et al. (Kirchler et al. 2007, 2008; Wahl et al. 2010) suggest that governments should try to increase their citizens' trust by taking a 'service and client' approach (increasing education and reducing the number of audits).

In this context, J. Alm and B. Torgler (2011) suggest that authorities could improve compliance by using a 'full house' of behaviours. They identify three paradigms: the 'enforcement' paradigm, the 'service' paradigm and the 'trust' paradigm. While explaining the role of each paradigm, they underline several constructive actions. According to them, the 'service' paradigm should treat taxpayers more as clients and less as potential criminals. All of the above studies share the same view and stress that educating citizens is a good policy in order to raise compliance. In reference to the 'enforcement' paradigm, in which authorities are suspicious towards taxpayers, it seems necessary for authorities to be powerful in order to get compliance by increasing the number of audits and the level of the fines (for a review, see Kirchler 2007). Regarding the 'trust' paradigm, as we have shown, it seems to be, in itself, a very important aspect in accepting to voluntary comply...

Once we have established that the better the knowledge is about taxation, the higher the voluntary tax compliance will be attained, what should be done in order to obtain a better 
knowledge about taxation? In order to reach a better level of knowledge, it seems obvious that we need to better educate the citizens, and the earlier it is started the better it should be. By saying this, we clearly cannot simply imply that teachers should just encourage tax compliance. Nevertheless, we trust that, if special sections of the teaching were focussing more on civic education, stressing the importance of the role of taxes, the various uses of taxes for improving shared public goods, and overall stating how the governments need taxes in order to develop many positive facets, showing how tax money can improve public services, such as schools, hospitals or roads, stressing the potential benefits for the whole society, children becoming adults might become more aware of the importance of paying taxes; they might even realize how useful their personal participation to public goods can really be...

\section{Conclusion}

Our results, based on a French sample of university students, are totally in line with those assumed in the 'slippery slope' framework (Kirchler 2007; Kirchler et al. 2008; Kirchler and Wahl 2010; Wahl et al. 2010); with our data, we have confirmed all the initial assumptions around the role of trust and power of tax authorities. In fact, our results have shown that trust and power of authorities influence tax compliance in two different forms: voluntary and enforced tax compliance. Our study supports the 'slippery slope' framework, and contributes to getting a better understanding of how taxpayers function and react, especially when they have a high trust in their government and when they perceive the power of their government as being strong, in which case they clearly tend to comply the most. 
In this article, we aimed at showing that tax fraud is a specific case of corruption, which is, especially when based on selfish motivations, a non-cooperative and competitive act, placing self-interest into the foreground instead of public interest. We opposed it to voluntary tax compliance, which we identified as an act of citizenship, involving a type of cooperation, placing public interest in the foreground, based on trust in the government.

In this context, we postulated that taxpayers, who declare all their income and who pay their taxes, are cooperative citizens. We have shown that, in terms of tax paying, cooperation, being based on trust and on a more or less equal relationship in which parties agree with certain goals, implies tax compliance; in that sense, voluntary compliance and cooperation work hand in hand. Nevertheless, we have also shown that compliance is not always connected to cooperation, as, when compliance is enforced, it is based on power and authority, along with threat of audits and fines.

In agreement with other results from various studies (Braithwaite 2003a, 2003b; Kirchler et al. 2007, 2008; Wahl et al. 2010; Alm and Torgler 2011), we confirmed that education should be a good mean to heighten the number of cooperative citizens, who would voluntarily comply. Therefore, educating the citizens around the use of taxes, helping them to understand the various uses of taxes for improving shared public goods, seems to be the first recommendation to limit tax evasion...

\section{References}

Allingham, M. G. and Sandmo, A. (1972), 'Income tax evasion: a theoretical analysis', Journal of Public Economics, 1:3-4, pp. 323-38. 
Alm, J. (1991), 'A perspective on the experimental analysis of taxpayer reporting', The Accounting Review, 66:3, pp. 577-93.

Alm, J. and Torgler, B. (2011), 'Do ethics matter? Tax compliance and morality', Journal of Business Ethics, 101:4, pp. 635-51.

Bohm, P. (1972), ‘Estimating demand for public goods: An experiment', European Economic Review, 3:2, pp. 111-30.

Braithwaite, V. (2003a), 'A new approach to tax compliance', in V. Braithwaite (ed.), Taxing Democracy. Understanding Tax Avoidance and Tax Evasion, Aldershot: Ashgate, pp. 1-11. (2003b), 'Dancing with tax authorities: Motivational postures and non-compliant actions', in V. Braithwaite (ed.), Taxing Democracy. Understanding Tax Avoidance and Tax Evasion, Aldershot: Ashgate, pp. 15-39.

Carnevale, P. J. and Probst, T. (1997), 'Good news about competitive people', in C. K. W. De Dreu and E. van de Vliert (ed.), Using Conflict in Organizations, London: Sage, pp. 129-46.

Chaudhuri, A. and Paichayontvijit, T. (2006), 'Conditional cooperation and voluntary contributions to a public good', Economics Bulletin, 3:8, pp. 1-14.

Crowe, M. T. (1944), 'The moral obligation of paying just taxes', The Catholic University of America Studies in Sacred Theology, no. 84.

Dawes, R. M. and Thaler, R. H. (1988), ‘Anomalies: Cooperation', The Journal of Economic Perspectives, 2:3, pp. 187-97.

Deutsch, M. (1949), 'A theory of cooperation and competition', Human Relations, 2, pp. $129-52$. 
Eriksen, K. and Fallan, L. (1996), 'Tax knowledge and attitudes towards taxation; A report on a quasi-experiment', Journal of Economic Psychology, 1:3, pp. 387-402. European Commsion (2012), 'Corruption', Special Barometer 374, http://ec.europa.eu/public_opinion/archives/ebs/ebs_374_en.pdf. Accessed 9 June 2012.

Fischbacher, U., Gächter, S. and Fehr, E. (2001), ‘Are people conditionally cooperative? Evidence from a public goods experiment', Economics Letters, 71:3, pp. 397-404.

Fischer, C. M., Wartick, M. and Mark, M. (1992), 'Detection probability and taxpayer compliance: A review of the literature', Journal of Accounting Literature, 11:1, pp. $1-46$.

Fülöp, M. (1992), 'Teachers' concepts on competition', Didaktisk Tidskrift, 9, pp. 46-57. (2003), 'Competition in Educational Settings', Centre for Educational Policy Studies, Faculty of Education, Slovenia: University of Ljubljana. (2004), 'Competition as a culturally constructed concept', in C. Baillie, E. Dunn and Y. Zheng (ed.), Travelling Facts. The Social Construction, Distribution, and Accumulation of Knowledge, Frankfurt/New York: Campus Verlag, pp. 124-48. (2008), 'Paradigmaváltás a versengés kutatásban’/‘Paradigm shift in competition research', Pszichológia/Psychology, 28:2, pp. 113-40. (2009), 'Socialization for cooperative and competitive citizen: A classroom observation study', Social Science Tribune. Special Issue: From a National Identity to a European One, 14:55, Summer, pp. 59-87. 
Griffin-Pierson, S. (1990), 'The competitiveness questionnaire: A measure of two components of competitiveness', Measurement and Evaluation in Counseling and Development, 23:3, pp. 108-15.

Groenland, E. A. and van Veldhoven, G. M. (1983), ‘Tax evasion behavior: A psychological framework', Journal of Economic Psychology, 3:2, pp. 129-44.

Harris, L. and Associates Inc. (1988), ‘1987 taxpayer opinion survey’, Conducted for the U.S. Internal Revenue Service, Internal Revenue Service Document 7292, Washington, DC.

Inglehart, R. (2000), Codebook for World Values Survey, Ann Arbor: Institute for Social Research.

Jackson, B. R. and Milliron, V. C. (1986), ‘Tax compliance research: Findings, problems and prospects', Journal of Accounting Litterature, 5, pp. 125-65.

Kemp, S. (2002), Public Goods and Private Wants: A Psychological Approach to Government Spending, Cheltenham: Edward Elgar.

Kirchler, E. (2007), The Economic Psychology of Tax Behavior, Cambridge, UK: Cambridge University Press.

Kirchler, E. and Maciejovsky, B. (2001), 'Tax compliance within the context of gain and loss situations, expected and current asset position, and profession', Journal of Economic Psychology, 22:2, pp. 173-94.

Kirchler, E. and Wahl, I. (2010), 'Tax compliance inventory TAX-I: Designing an inventory for surveys of tax compliance', Journal of Economic Psychology, 31:3, pp. 331-46. 
Kirchler, E., Hoelzl, E. and Wahl, I. (2008), ,Enforced versus voluntary tax compliance: The "slippery slope" framework', Journal of Economic Psychology, 29:2, pp. 21025.

Kirchler, E., Muehlbacher, S., Kastlunger, B. and Wahl, I. (2007), ,Why pay taxes? A review of tax compliance decisions', in J. Martinez-Vasquez, B. Torgler and J. Alm (ed.), Developing Alternative Frameworks for Explaining Tax Compliance, Abingdon, Oxon: Routledge, pp. 15-31.

Laffont, J.-J. (1975), 'Macroeconomic constraints, economic efficiency and ethics: An introduction to Kantian economics', Economica, 42:168, pp. 430-37.

Ledyard, J. O. (1995), 'Public goods: A survey of experimental research', in J. H. Kagel and A. E. Roth (ed.), The Handbook of Experimental Economics, Princeton: Princeton University Press, pp. 111-251.

McGee, R. W. (2006), 'Three views on the ethics of tax evasion', Journal of Business Ethics, 67:1, pp. 15-35.

National Constituent Assembly (2012), 'Declaration of the rights of man and of the citizen of 1789', http://www.historyguide.org/intellect/declaration.html. Accessed 3 May 2012.

Olson, M. (1971), The Logic of Collective Action: Public Goods and the Theory of Groups, Harvard, USA: Harvard University Press.

Organization for Economic Co-operation and Development_(OECD) (2012), 'Civic engagement', http://www.oecdbetterlifeindex.org/topics/civic-engagement/. Accessed 12 November 2012. 
Park, C.-G. and Hyun, J. K. (2003), 'Examining the determinants of tax compliance by experimental data: a case of Korea', Journal of Policy Modeling, 25:8, pp. 673-84.

Richardson, G. (2008), 'The relationship between culture and tax evasion across countries: Additional evidence and extensions', Journal of International Accounting, Auditing and Taxation, 17:2, pp. 67-78.

Srinivasan, T. N. (1973), 'Tax evasion: A model', Journal of Public Economics, 2:4, pp. $339-46$.

Sugden, R. (1984), 'Reciprocity: The supply of public goods through voluntary contributions', Economic Journal, 94:376, pp. 772-87.

Tassi, F. and Schneider, B. H. (1997), 'Task-oriented versus other-referenced competition: Differential implications for children's peer relations', Journal of Applied Social Psychology, 27:17, pp. 1557-80.

Torgler, B. (2003), 'Tax morale, rule-governed behaviour and trust', Constitutional Political Economy, 14:2, pp. 119-40.

Torgler, B. and Schneider, F. (2005), 'Attitudes towards paying taxes in Austria: An empirical analysis', Empirica, 32:2, pp. 231-50.

Transparency International (2011), 'Corruption perception index', http://cpi.transparency.org/cpi2011/results/. Accessed 9 June 2012. (2012), 'Definition of corruption', http://www.transparency.org/whoweare/organisation/faqs_on_corruption. Accessed 11 November 2012. 
Tsakumis, G. T., Curatola, A. P. and Porcano T. M. (2007), 'The relation between national cultural dimensions and tax evasion', Journal of International Auditing and Taxation, 16, pp. 131-47.

United Nations (2012), 'Universal declaration of human rights', http://www.un.org/en/documents/udhr/index.shtml. Accessed 3 May 2012.

van de Vliert, E. (1999), 'Cooperation and competition as partners', European Review of Social Psychology, 10:1, pp. 231-57.

Wahl, I., Kastlunger, B. and Kirchler, E. (2010), 'Trust in authorities and power to enforce tax compliance: An empirical analysis of the "Slippery Slope Framework", Law \& Policy, 32:4, pp. 383-406.

Weigel, R. H., Hessing, D. J. and Elffers, H. (1987), 'Tax evasion research: A critical appraisal and theoretical model', Journal of Economic Psychology, 8:2, pp. 215-35.

\section{Contributor details}

Jérémy Lemoine is a Ph.D. student in Social Psychology at the University of Rheims Champagne-Ardenne, France. Jérémy's research focuses on decision making and risk taking in different context e.g. tax, gambling, competition. He is interested in studying how intra-individual factors, such as self-esteem, and inter-individual factors, like education, influence the behaviour. He works as a work organizational psychologist at the University Hospital of Reims. He analyses causes of organizational difficulties and suggests recommendations in order to improve them.

Christine Roland-Lévy is a University Professor in Psychology, at the University of 
Rheims Champagne-Ardenne, in France. She has been President of a series of international research Associations, among which are the International Association for Research in Economic Psychology, as well as Children's Identity and Citizenship:

European Association. She teaches social and economic psychology at the Master's level, and her research projects focus around societal issues in the context of the financial and economic crisis. The main theoretical keywords are social representations, socialization and conducts. She co-edited seven academic international books, edited four manuals for students and professionals, co-edited special issues for the Journal of Economic Psychology, New Review of Social Psychology, Applied Psychology: An International Review, and Citizenship Teaching and Learning, and published more than 50 articles in international academic journals, with quite a few on societal issues, including on identity and citizenship.

\section{Contact:}

Jérémy LEMOINE, Université de Reims Champagne-Ardenne, Département de

Psychologie,57 rue Pierre Taittinger, F-51096 Reims cedex.

E-mail: j.lemoine86@gmail.com

Christine ROLAND-LEVY, Université de Reims Champagne-Ardenne, Département de Psychologie,57 rue Pierre Taittinger, F-51096 Reims cedex.

E-mail: Christine.Roland-Levy@,univ-reims.fr

Notes 
${ }^{1}$ The Eurobarometer is based on a series of surveys carried out in the European Union countries.

${ }^{2}$ A public good game is an experiment in which people have to spend a certain amount of money; in the game, they can keep money for themselves or invest it in a public good project.

${ }^{3}$ Free-riders are people who behave in an egocentric way.

${ }^{4}$ Conditional cooperators are people who are willing to contribute to public good as long as others also contribute.

5 The 'Kantian' rule refers to the following: 'Human nature in some economic circumstances is capable of behavior other than the selfish pattern imputed to the "homo œconomicus" by economic theory’ (Laffont 1975).

${ }^{6}$ For more information see R. Inglehart (2000) for WVS and EVS and L. Harris and Associates Inc. (1988) for TOS.

${ }^{7}$ The variation of the perception of trust can be observed in Figure 2.

${ }^{8}$ The variation of the perception of power can be observed in Figure 2.

${ }^{9}$ Mean and standard deviation of tax compliance by group are presented in Table 1.

${ }^{10}$ Mean and standard deviation of voluntary tax compliance by group are presented in Table 1. 
${ }^{11}$ Mean and standard deviation of enforced tax compliance by group are presented in Table 1.

${ }^{12}$ Mean and standard deviation of tax evasion by group are presented in Table 1. 